IRA-International Journal of Management \& Social Sciences

ISSN 2455-2267; Vol.11, Issue 02 (May 2018)

Pg. no. 69-86.

Institute of Research Advances

http://research-advances.org/index.php/RAJMSS

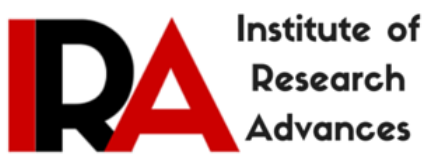

\title{
An Empirical Study on Socio-Economic Conditions of Fishermen of North-East Coastal Region of India
}

Dr. Amit Majumder, M.Com, M.Phil, M.B.A.,Ph.D., Ph.D. (Commerce)

Assistant Professor of Commerce (St.III) \& Head, Dept of Commerce (UG \& PG)

Bijoy Krishna Girls' College, Howrah, India.

Type of Review: Peer Reviewed.

DOI: http://dx.doi.org/10.21013/jmss.v11.n2.p2

How to cite this paper:

Majumder, A.(2018). An Empirical Study on Socio-Economic Conditions of Fishermen of North-East Coastal Region of India. IRA-International Journal of Management \& Social Sciences (ISSN 2455-2267), 11(2), 69-86. doi:http://dx.doi.org/10.21013/jmss.v11.n2.p2

(C) Institute of Research Advances.

\section{(cc) BY-NC}

This work is licensed under a Creative Commons Attribution-Non Commercial 4.0 International License subject to proper citation to the publication source of the work.

Disclaimer: The scholarly papers as reviewed and published by the Institute of Research Advances (IRA) are the views and opinions of their respective authors and are not the views or opinions of the IRA. The IRA disclaims of any harm or loss caused due to the published content to any party.

Institute of Research Advances is an institutional publisher member of Publishers Inter Linking Association Inc. (PILA-CrossRef), USA. The institute is an institutional signatory to the Budapest Open Access Initiative, Hungary advocating the open access of scientific and scholarly knowledge. The Institute is a registered content provider under Open Access Initiative Protocol for Metadata Harvesting (OAI-PMH).

The journal is indexed \& included in WorldCat Discovery Service (USA), CrossRef Metadata Search (USA), WorldCat (USA), OCLC (USA), Open J-Gate (India), EZB (Germany) Scilit (Switzerland), Airiti (China), Bielefeld Academic Search Engine (BASE) of Bielefeld University, Germany, PKP Index of Simon Fraser University, Canada. 


\section{Introduction}

Fishing is recognised as a source of food since the Stone Age. A fisherman is the one who is involved in the process of capturing fish and other species from a water body for living and earning purposes, which started with an objective of survival and transformed into a source of business. According to the Food and Agriculture Organisation (FAO) of the United Nations, fish output in India doubled between 1990 and 2010. India acquires 8129 kilometres of marine coastline involving over 1.5 million people who are directly or indirectly related to fishing industry. Being a natural consumable resource it contributes to food security of India, fish is considered as a consumable source and an income source simultaneously. Traditionally, there exist primarily two forms of fishing-Inland Fishing and Marine Fishing. While the former is preferable to the local customers in India due to variety of tastes, on the other hand the Marine Fishing is considered as one of the significant foreign exchange earners as well as suppliers of huge nutritional requirements for this vast population. Nearly 60 per cent of Indian fish productions are coming from coastal fishing. To step up deep-sea fishing activities, in 1977 the Government extended its territorial control over 200 nautical miles in the ocean. This zone was termed as 'Exclusive Economic Zone' (EEZ). About 6.3\% of global fish production as well as 1.1\% of Indian GDP and $5.15 \%$ of agricultural GDP is contributed by Indian fishing industry.

Table\#1: Contribution of India to World Fish Production

\begin{tabular}{|c|c|c|c|c|c|c|}
\hline \multicolumn{7}{|c|}{ Contribution of India to World Fish Production } \\
\hline \multicolumn{7}{|c|}{ (In ' 000 Tonne) } \\
\hline \multirow[t]{2}{*}{ Year } & \multicolumn{3}{|c|}{ World Production } & \multicolumn{3}{|c|}{ Contribution of India } \\
\hline & Total & Marine & Inland & Total & Marine & Inland \\
\hline 1950 & 19755 & 17521 & 2234 & 730 & 520 & 210 \\
\hline 1955 & 28641 & 24968 & 3673 & 839 & 596 & 243 \\
\hline 1960 & 36691 & 32665 & 4026 & 1162 & 880 & 282 \\
\hline 1965 & 51229 & 46141 & 5088 & 1331 & 824 & 507 \\
\hline 1970 & 67280 & 61277 & 6003 & 1759 & 1086 & 673 \\
\hline 1975 & 68341 & 61481 & 6860 & 2267 & 1482 & 785 \\
\hline 1980 & 75586 & 67953 & 7633 & 2446 & 1555 & 891 \\
\hline 1985 & 91553 & 80888 & 10665 & 2839 & 1747 & 1092 \\
\hline 1990 & 103590 & 88997 & 14593 & 3875 & 2300 & 1575 \\
\hline 1991 & 98261 & 84664 & 13597 & 4045 & 2390 & 1655 \\
\hline 1992 & 100885 & 86329 & 14556 & 4232 & 2512 & 1720 \\
\hline 1993 & 104477 & 88351 & 16126 & 4606 & 2676 & 1930 \\
\hline 1994 & 112559 & 94659 & 17900 & 4785 & 2796 & 1989 \\
\hline 1995 & 116411 & 96220 & 20191 & 4951 & 2754 & 2197 \\
\hline 1996 & 120199 & 98038 & 22161 & 5231 & 2910 & 2321 \\
\hline 1997 & 122542 & 98783 & 23759 & 5385 & 2949 & 2436 \\
\hline 1998 & 117790 & 92593 & 25197 & 5275 & 2763 & 2512 \\
\hline 1999 & 126651 & 99468 & 27183 & 5592 & 2848 & 2744 \\
\hline 2000 & 130433 & 101831 & 28602 & 5689 & 2852 & 2837 \\
\hline 2001 & 131002 & 101550 & 29452 & 5897 & 2930 & 2967 \\
\hline 2002 & 133651 & 102953 & 30698 & 5924 & 3107 & 2817 \\
\hline 2003 & 133187 & 101828 & 31359 & 6025 & 3107 & 2918 \\
\hline 2004 & 140492 & 103796 & 36696 & 6190 & 2989 & 3201 \\
\hline 2005 & 142691 & 103401 & 39290 & 6658 & 2995 & 3663 \\
\hline 2006 & 143648 & 101990 & 41658 & 7014 & 3159 & 3855 \\
\hline
\end{tabular}

Consistency in growth of both inland fish production and marine fish procurement can be noticed throughout the years in comparison to the world. Since 1950 Indian fishing industry went through minor disruptions as the economy was not stable and trying to cope up with rapid structural changes but since 1991 post liberalisation privatisation and globalisation the industry triggered its pace and managed a steady growth all these years. This 
industry has also emerged as a contributing sector to GDP. Table 1 represents the rise and fall of the fishing industry in terms of fish catches each year in thousand tonnes.

Table\#2:Fish Production of Marine and Inland in India

\begin{tabular}{|c|c|c|c|}
\hline \multicolumn{4}{|c|}{ Fish Production of Marine and Inland in India } \\
\hline \multicolumn{4}{|c|}{ (In ' 000 Tonne) } \\
\hline Years & Marine & Inland & Total \\
\hline $1950-51$ & 534 & 218 & 752 \\
\hline $1955-56$ & 596 & 243 & 839 \\
\hline 1960-61 & 880 & 280 & 1160 \\
\hline 1965-66 & 824 & 507 & 1331 \\
\hline 1970-71 & 1086 & 670 & 1756 \\
\hline 1973-74 & 1210 & 748 & 1958 \\
\hline 1978-79 & 1490 & 816 & 2306 \\
\hline $1979-80$ & 1492 & 848 & 2340 \\
\hline 1980-81 & 1555 & 887 & 2442 \\
\hline 1981-82 & 1445 & 999 & 2444 \\
\hline $1982-83$ & 1427 & 940 & 2367 \\
\hline 1983-84 & 1519 & 987 & 2506 \\
\hline 1984-85 & 1698 & 1103 & 2801 \\
\hline $1985-86$ & 1716 & 1160 & 2876 \\
\hline 1986-87 & 1713 & 1229 & 2942 \\
\hline 1987-88 & 1658 & 1301 & 2959 \\
\hline 1988-89 & 1817 & 1335 & 3152 \\
\hline 1989-90 & 2275 & 1402 & 3677 \\
\hline 1990-91 & 2300 & 1536 & 3836 \\
\hline 1991-92 & 2447 & 1710 & 4157 \\
\hline $1992-93$ & 2576 & 1789 & 4365 \\
\hline 1993-94 & 2649 & 1995 & 4644 \\
\hline 1994-95 & 2692 & 2097 & 4789 \\
\hline 1995-96 & 2707 & 2242 & 4949 \\
\hline 1996-97 & 2967 & 2381 & 5348 \\
\hline $1997-98$ & 2950 & 2438 & 5388 \\
\hline 1998-99 & 2696 & 2602 & 5298 \\
\hline 1999-00 & 2852 & 2823 & 5675 \\
\hline 2000-01 & 2811 & 2845 & 5656 \\
\hline 2001-02 & 2830 & 3126 & 5956 \\
\hline 2002-03 & 2990 & 3210 & 6200 \\
\hline 2003-04 & 2941 & 3458 & 6399 \\
\hline 2004-05 & 2779 & 3526 & 6305 \\
\hline 2005-06 & 2816 & 3756 & 6572 \\
\hline 2006-07 & 3024 & 3845 & 6869 \\
\hline 2007-08 & 2920 & 4207 & 7127 \\
\hline 2008-09 & 2978 & 4638 & 7616 \\
\hline 2009-10 & 3104 & 4894 & 7998 \\
\hline
\end{tabular}


IRA-International Joumal of Management Eి Social Sciences

\begin{tabular}{|l|l|l|l|}
\hline $2010-11$ & 3250 & 4981 & 8231 \\
\hline $2011-12$ & 3372 & 5294 & 8666 \\
\hline $2012-13$ & 3321 & 5719 & 9040 \\
\hline $2013-14$ & 3444 & 6132 & 9576 \\
\hline $2014-15$ & 3502 & 6929 & 10431 \\
\hline $2015-16(P)$ & 3583 & 7213 & 10795 \\
\hline Abbr.: (P): Provisional. & \\
\hline Source: Central Water Commission, Govt. of India. & \\
\hline Ministry of Agriculture, Govt. of India. & \\
\hline Ministry of Statistics and Programme Implementation, Govt. of India. \\
\hline Ministry of Agriculture \& Farmers Welfare, Govt. of India \\
\hline
\end{tabular}

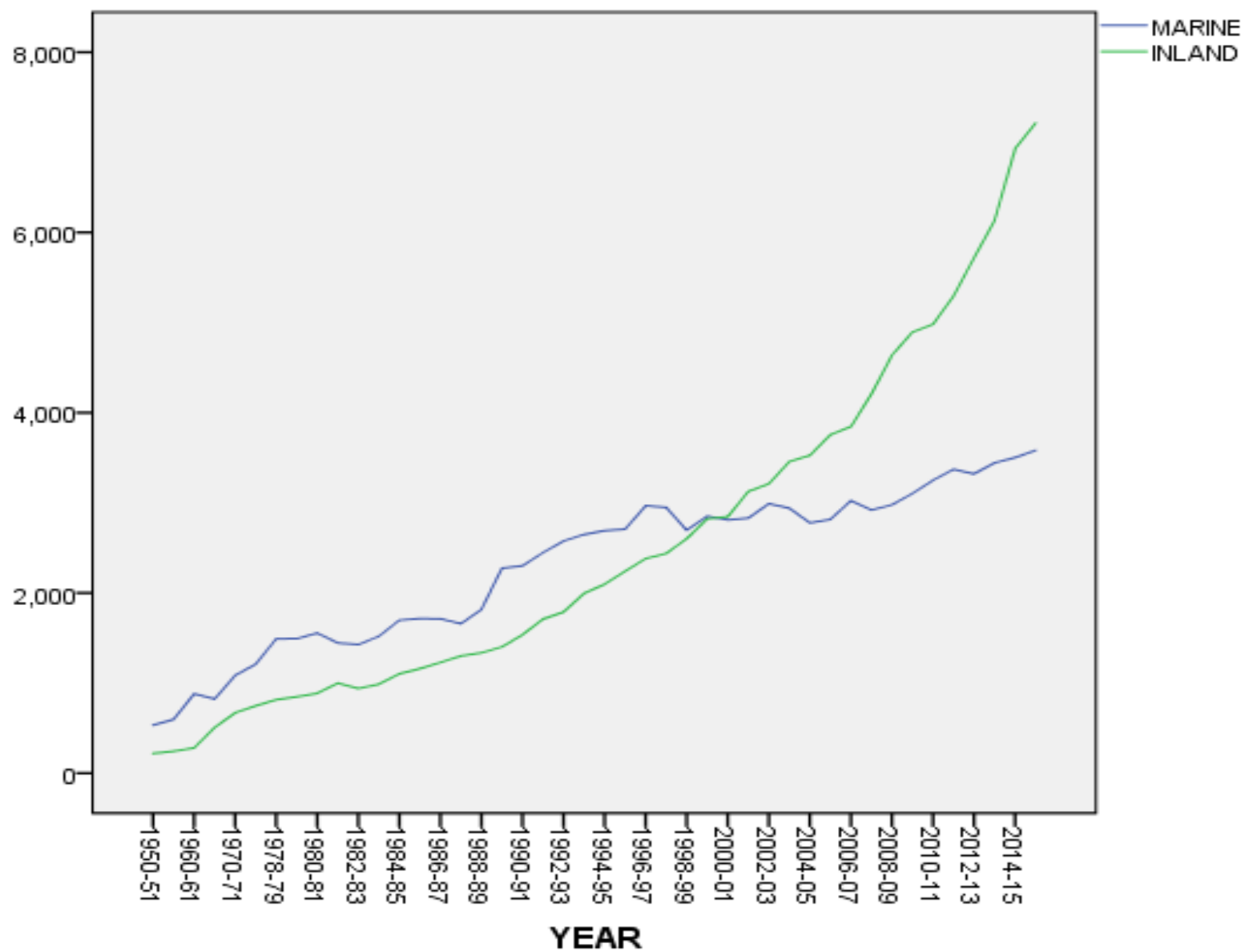

Marine fisheries encountered a growth of 6.71 times in 2015-16 with comparison to the year 1950-51. This is a positive indicator of Indian fisheries all over the years. Comparing the growth of Inland fisheries to marine fisheries, 33.1 times growth is noticed in current year in respect to 1950-51. The overall growth is 14.35 times of what it was in 1950-51. The above table 2 depicts the pattern of improvements of fish production and procurement that have taken place along with progress in time throughout these years. Development noticed nowadays is the consolidated efforts of several years that have made this condition possible for India. The transformation of this industry can be analysed if the year 1950-51 is compared to the year 2015-16 where the inland fish production and catch amounted to 2,18,000 thousand tonne while in the year 2015-16 72,13,000 thousand tonne of inland fish was produced which is approximately $3308 \%$ rise in respect to base year. Again on the other hand marine fish procurement in the year 2015-16 amounted to 3,583 thousand tonne which stood at 534 thousand tonne in the year 1950-51. Accumulated fish production showed a positive growth of 14.36 times more than the base year 1950-51. 
Table\#3:State-wise Marine Fish Production in India

\begin{tabular}{|c|c|c|c|c|c|c|c|c|c|c|}
\hline \multicolumn{11}{|c|}{ State-wise Marine Fish Production in India } \\
\hline \multicolumn{11}{|c|}{ (2007-2008 to 2016-2017-upto December 2017) } \\
\hline \multicolumn{11}{|c|}{ (In Lakh Tonne) } \\
\hline \multirow[t]{2}{*}{ States/UTs } & 2007- & 2008- & 2009- & 2010- & 2011- & 2012- & 2013- & 2014- & 2015- & 2016- \\
\hline & 2008 & 2009 & 2010 & 2011 & 2012 & 2013 & 2014 & 2015 & $2016 *$ & $2017 * \#$ \\
\hline $\begin{array}{l}\text { Andaman and } \\
\text { Nicobar Islands }\end{array}$ & 0.29 & 0.32 & 0.33 & 0.34 & 0.35 & 0.36 & 0.37 & 0.37 & 0.37 & 0.30 \\
\hline $\begin{array}{l}\text { Andhra } \\
\text { Pradesh }\end{array}$ & 2.55 & 2.91 & 2.93 & 2.89 & 4.33 & 4.14 & 4.38 & 4.75 & 5.20 & 4.01 \\
\hline Daman and Diu & 0.26 & 0.14 & 0.16 & 0.17 & 0.17 & 0.19 & 0.19 & 0.32 & 0.23 & 0.18 \\
\hline Goa & 0.32 & 0.83 & 0.82 & 0.90 & 0.86 & 0.74 & 1.10 & 1.15 & 1.07 & 0.10 \\
\hline Gujarat & 6.45 & 6.23 & 6.87 & 6.89 & 6.92 & 6.94 & 6.96 & 6.98 & 6.97 & 5.03 \\
\hline Karnataka & 1.76 & 2.18 & 1.71 & 3.41 & 3.47 & 3.57 & 3.57 & 4.57 & 4.12 & 2.86 \\
\hline Kerala & 5.86 & 5.83 & 5.70 & 5.60 & 5.53 & 5.31 & 5.22 & 5.24 & 5.17 & 2.98 \\
\hline Lakshadweep & 0.11 & 0.13 & 0.12 & 0.12 & 0.12 & 0.12 & 0.19 & 0.13 & 0.12 & 0.02 \\
\hline Maharashtra & 4.20 & 3.96 & 4.16 & 4.47 & 4.34 & 4.49 & 4.67 & 4.64 & 4.34 & 3.49 \\
\hline Odisha & 1.31 & 1.35 & 1.29 & 1.33 & 1.14 & 1.18 & 1.20 & 1.33 & 1.45 & 0.14 \\
\hline Pondicherry & 0.33 & 0.35 & 0.36 & 0.36 & 0.38 & 0.36 & 0.38 & 0.42 & 0.78 & 0.36 \\
\hline Tamil Nadu & 3.93 & 3.65 & 3.65 & 4.05 & 4.27 & 4.28 & 4.32 & 4.57 & 4.67 & 0.82 \\
\hline West Bengal & 1.83 & 1.89 & 1.79 & 1.97 & 1.82 & 1.52 & 1.88 & 1.79 & 1.78 & 1.30 \\
\hline India & 29.19 & 29.78 & 29.90 & 32.49 & 33.72 & 33.21 & 34.43 & 36.26 & 36.27 & 21.59 \\
\hline \multicolumn{11}{|l|}{ *: Provisional. } \\
\hline \multicolumn{11}{|c|}{ \# : Up to December 2017.} \\
\hline \multicolumn{11}{|c|}{ Source : Ministry of Agriculture, Govt. of India. } \\
\hline \multicolumn{11}{|c|}{ LokSabha Starred Question No. 222, dated on 02.08 .2016 \& } \\
\hline \multicolumn{11}{|c|}{ LokSabhaUnstarred Question No. 4032, dated on 27.03.2017. } \\
\hline
\end{tabular}

States and islands having sea borders enjoy the privilege of marine fishing very smoothly. These states contribute most of the marine fish catch and develop a business opportunity of trading these fishes to other states which are mostly dependent on inland fisheries. Data in table 3 represents fish production of those states or islands which are surrounded with sea borders. Gujarat is noticed to be the leader in marine fishing followed by Kerala, Maharashtra, Tamil Nadu, Andhra Pradesh, etc. these states have also shown a simultaneous growth throughout these years. While states like Pondicherry, West Bengal, Odisha, Lakshadweep, Daman and Diu, Andaman and Nicobar Islands, etc. have consistently maintained their stability and have not reflected any growth in past ten years. The table shows the states that are contributing to the fishing industry and also states that do not contribute to the growth of fisheries in India rather holding the position. Fishing in India lags behind not due to factors like unrecognised sector, less governmental aid or underdeveloped skill rather the industry is weak due to improper financing and lack of modern techniques. Small and medium type of fishing is still skill based and old school technique of fishing is followed. Where the experienced fisherman goes for fishing with few other inexperienced personnel and on the basis of assumption without any technology catches fish with medium sized boat and medium sized fishing net.

One of the major impediments in the Indian marine fishing industry is the availability of credit or financing issue. The credit requirements of the fishers and fish farmers are being largely met through institutional sources. Nevertheless, the critical role of the middlemen, merchants and traditional money lenders in the chain is still in vogue. However, the present liberal policies of the banking sector hold a considerable hope for improvement particularly in the fishery sector. In order to ensure remunerative returns to the fishermen, it is necessary to organise marketing channels supported by adequate facilities ensuring reasonable prices. Budgetary support for research, infrastructural development, training and extension for the culture based activities need to be enhanced greatly considering the potential of the sector. 
Fishing at sea has been recognized as the most dangerous occupation in the world. The data gathered from countries that keep accurate records show that occupational facilities in those countries fishing industries far exceed the overall national averages. Future welfare programmes should be oriented towards sea safety measures, especially for the artisanal and small-scale fishermen. In general, the fisheries sector needs a sound and implementable policy and legal framework which can enable a gradual shift in the priorities from fisher welfare measures to development of sustainable fisheries and aquaculture.

Moreover, due to the hazardous nature of sea, fishing often results in loss of life, fishing boats and implements, besides injury and permanent impairment. Recent studies have pointed out that calamities occur mostly due to ill-equipped vessels and non-availability of an early warning system on the boat. This component is intended to improve the sea safety to reduce loss of human life and property at sea.

Finally a number of research studies [Ralph(1957), Hakkim(1980), Kurien (1981), Sehara (1984), Rajan (2014)] had revealed the plight of coastal fishermen household in India suffering from acute poverty, income inequalities, occupational hazards, growing indebtedness, low literacy and pseudo unemployment. However, the researchers have not come across any intensive study covering coastal fishermen in North-Eastern coastal region of India (with more than $11 \%$ share of total coastline in India)which encourages the researchers to fill the research gap and throw light in this subject based on serious socio-economic empirical study on the fishermen, their households and allied parameters/mechanisms.

\section{Objective of Study:}

In this backdrop the present study is envisaged to observe the following:-

I. A brief profile of marine fish production in coastal areas in India in general and north eastern part consisting with West Bengal in particular,

II. To critically observe the economic status of fishermen by revealing the underlying market mechanism and price dynamics of end products,

III. To observe the occupational pattern and allied occupational hazards in this present industry.

\section{Research Methodology:}

Survey Area

Digha is assumed to be the most curtail fishing point in west Bengal and most of the trade of marine fish takes place in Digha either be it import or export. So the fishing industry is dependent on trading points like Digha and the study focuses to draw some references on current standard of living based on fishermen residing over here. Assessment of the benefits or demerits of an occupation that is being practiced by these men for so many years is also a concern of this study.

\section{Sample Size}

To attain the insights of the socio economic conditions of fishermen in Digha, a representative sample of seventy fishermen have been randomly selected from two densely populated villages of fishermen named Gadhadarpur and Duttapur. As Digha holds a strong position in the marine fisheries in West Bengal so a reference of the population can be dawned on the basis of the sample drawn.

\section{Data Collection}

The present study is based basically on primary and secondary data. The primary data is collected by conducting field study and interview with the fishermen of Digha through well designed questionnaire. Secondary data is gathered from both internal and external sources; organizational websites/ papers/annual reports and documents constitute the main source of internal secondary data; for external secondary sources we had rely on published documents, books, magazines, journals, papers, blogs etc.

\section{Research Design}

Keeping in mind the restricting time and cost factors, data collection process have been conducted through sample survey with the fishermen by the help of questionnaire (drafted mainly in Bengali for the convenience of the beneficiaries) prepared with the help of experts in this field; survey is conducted mainly on the grounds like family strength, education of fishermen and family, decision making abilities in family, society and panchayat or gram sabha, fishing income, cost of fishing, savings, services available, assessment of aids by government etc.; these data are compiled and analysed for interpretation after collection; conclusion of the report with summarized findings followed by limitations of the study and scope for further research. 


\section{Findings of the Study}

Data analysis

The study has been conducted on the fishermen of Digha,West Bengal on the basis of simple random sampling to uphold the current scenario of the fishermen who are involved in this industry. Fishermen of two specific villages are the respondents of the study. Villages that were taken into consideration are Gadadharpur and Duttapur, of which seventy fishermen were interrogated on the basis of questioners generated. The sample can be accepted as a representative sample of the population as these villages consist mostly of people who are engaged in fishing or were engaged in fishing. All the fishermen in the study are male and negligence of women workforce is noticed as the job involves risking their lives so the men takes the duty to generate income through fishing. Wives of the fishermen are mostly engaged in household works, Mahatma Gandhi National Rural Employment Guarantee Act and Self Help Group. All the respondents are Hindu and 2 out of 70 fishermen belong to general category while the remaining 68 respondents are Other Below Caste.

\begin{tabular}{|c|c|c|c|c|c|c|}
\hline \multicolumn{7}{|c|}{$\begin{array}{l}\text { Selected State-wise Marine Fisheries Resources of India } \\
\qquad(2014-2015)\end{array}$} \\
\hline States/UTs & $\begin{array}{r}\text { Approx. } \\
\text { Length } \\
\text { of Coast } \\
\text { Line } \\
\text { (In Kms.) }\end{array}$ & $\begin{array}{r}\text { Continental } \\
\text { Shelf } \\
\text { (' 000 Sq. } \\
\text { Kms.) }\end{array}$ & $\begin{array}{r}\text { Numbe } \\
r \text { of } \\
\text { Landing } \\
\text { Centres }\end{array}$ & $\begin{array}{r}\text { Numbe } \\
r \text { of } \\
\text { Fishing } \\
\text { Villages }\end{array}$ & $\begin{array}{r}\text { Number of } \\
\text { Fishermen Families }\end{array}$ & $\begin{array}{r}\text { Fisherfol } \\
\mathrm{k} \\
\text { Population }\end{array}$ \\
\hline $\begin{array}{l}\text { Andaman and } \\
\text { Nicobar Islands }\end{array}$ & 1912 & 35 & 16 & 134 & 4861 & 22188 \\
\hline Andhra Pradesh & 974 & 33 & 353 & 555 & 163427 & 605428 \\
\hline Daman and Diu & 27 & 0 & 5 & 11 & 7374 & 40016 \\
\hline Goa & 104 & 10 & 33 & 39 & 2189 & 10545 \\
\hline Gujarat & 1600 & 184 & 121 & 247 & 62231 & 336181 \\
\hline Karnataka & 300 & 27 & 96 & 144 & 30713 & 167429 \\
\hline Kerala & 590 & 40 & 187 & 222 & 118937 & 610165 \\
\hline Lakshadweep & 132 & 4 & 10 & 10 & 5338 & 34811 \\
\hline Maharashtra & 720 & 112 & 152 & 456 & 81492 & 386259 \\
\hline Odisha & 480 & 26 & 73 & 813 & 114238 & 605514 \\
\hline Puducherry & 45 & 1 & 25 & 40 & 14271 & 54627 \\
\hline Tamil Nadu & 1076 & 41 & 407 & 573 & 192697 & 802912 \\
\hline West Bengal* & 158 & 17 & 59 & 188 & 76981 & 380138 \\
\hline India & 8118 & 530 & 1537 & 3432 & 874749 & 4056213 \\
\hline
\end{tabular}

According to the above table a comparative analysis can be made for different states and their fisherfolk involved. Gujarat, Maharashtra, Andhra Pradesh and Tamil Nadu has the longest area of coastline when compared to other states but relatively number of fishermen involved in the fishing industry is low in case of Gujarat and Maharashtra. Landing centres are the places where fishes are landed after they are caught from sea. Tamil Nadu, Andhra Pradesh, Kerala, Maharashtra and Gujarat have the highest landing centres to provide better amenities of trade to this industry. West Bengal covers an area of 158 kilometres with continental shelf of 17,000 square kilometres and fifty nine landing centres. 188 fishing village includes 76,981 fishermen family and 3, 80,138 fishermen.

\begin{tabular}{|c|c|}
\hline AGE GROUP & NUMBER OF FISHERMEN \\
\hline $18-28$ & 8 \\
\hline $28-38$ & 17 \\
\hline $38-48$ & 23 \\
\hline $48-58$ & 18 \\
\hline
\end{tabular}




\begin{tabular}{|c|c|}
\hline $58-68$ & 4 \\
\hline TOTAL & 70 \\
\hline
\end{tabular}

Source: Field Survey

Rural population of India is considered to be poor, low standard of living and illiterate but what is these factors also make them hard working, motivated and self-dependent. Age group of fishermen is the perfect example to present the image of rural hardworking people as most of the respondents belong to the age group of 28-58. Twenty three fishermen belong to the age group of 38-48 referring that the job is better performed with experience and time. There are other reasons for non-involvement of fresh workforce as the wage rate is compatively lower than other activities and education has also changed the traditional way of thinking.

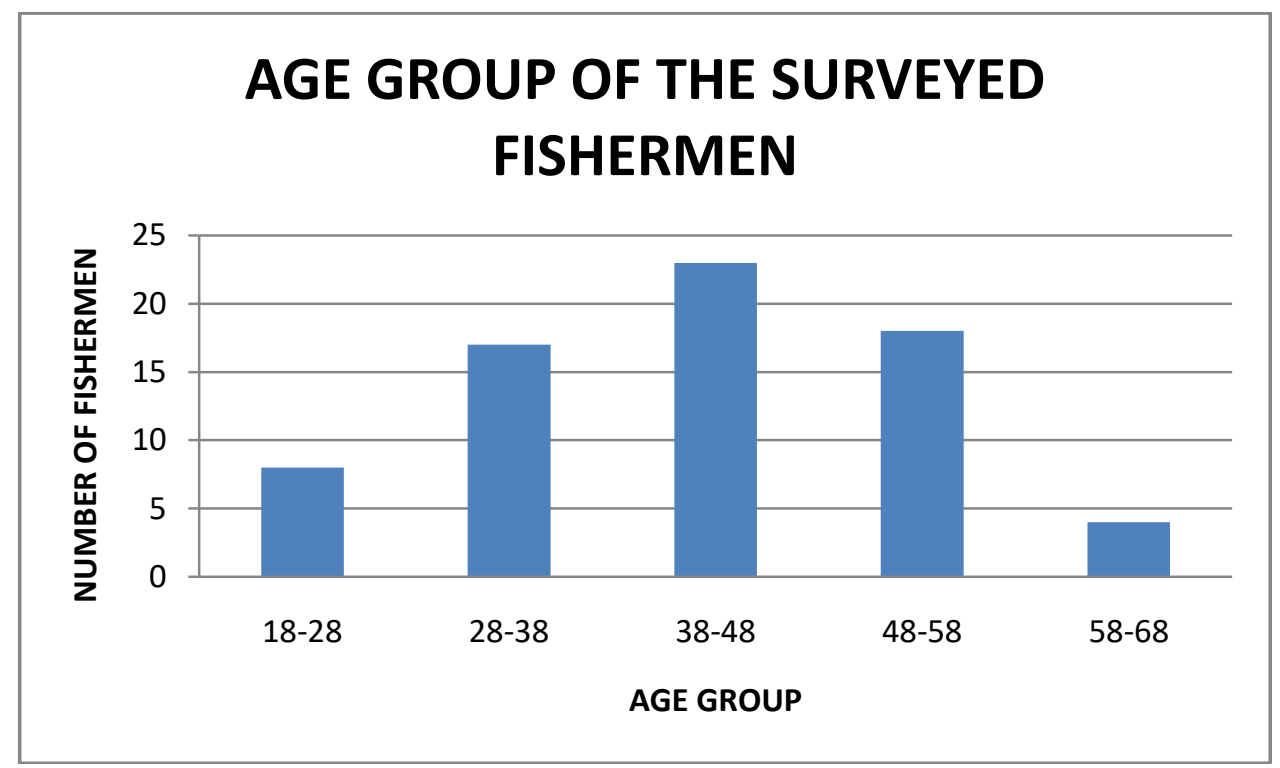

Source: Field Survey

Thirty seven of the fishermen went to primary school and are equivalent to uneducated as they can only read and write but cannot utilise education as a weapon against odds in living. Twenty six of them are class eight qualified which is also not helpful and the academic score is also not effective enough. Not even $10 \%$ of the sample went through higher education, only three of these respondents qualified for higher secondary and two fishermen were able to complete their graduation.

\begin{tabular}{|l|r|}
\hline EDUCATION QUALIFICATION OF THE & NUMBER \\
FISHERMEN & 2 \\
\hline CAN WRITE & 37 \\
\hline PRIMARY SCHOOL & 26 \\
\hline CLASS 8 & 3 \\
\hline MADHYAMICK & 2 \\
\hline GRADUATE & 70 \\
\hline TOTAL & \\
\hline
\end{tabular}

Source: Field Survey 


\section{EDUCATION QUALIFICATION OF THE SURVEYED FISHERMEN}

$\square$ CAN WRITE $\square$ PRIMARY SCHOOL $\square$ CLASS $8 \square$ MADHYAMICK $\square$ GRADUATE

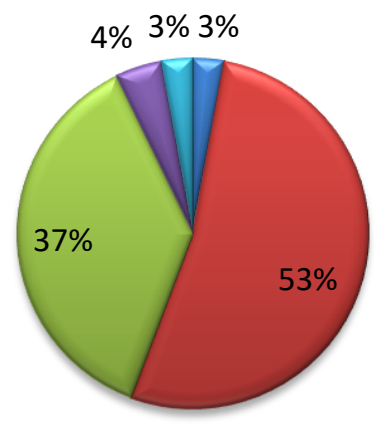

Source: Field Survey

The chart above represents the percentage of the sample and their qualifications. 53\% of the sample has gone to primary school. But things have change since generation have changed as people now believe in education and are enthusiastic in educating their children and encouraging them to take higher studies. All the fishermen do agree to the fact that lack of education has drastically harmed their lives and the awareness for education can be felt. The study reveals the strong mind setup of these fishermen as all the children are now getting primary education and higher education according to their age. 5 children of these fishermen who can't read or write has a supportive cause that these are baby who are not eligible for primary education on the basis of age. Wives of these fishermen are also not qualified enough due to generation gap and are not efficient enough to teach them by any personal means. Five of the respondents are not having children at this moment and 30 of them are not blessed with a girl child but no discrepancies can be noticed in case of education.

\begin{tabular}{|l|r|r|r|r|}
\hline \multicolumn{5}{|c|}{ FAMILY EDUCATION } \\
\hline & WIFE & \multicolumn{1}{l|}{ SON } & DAUGHTER & OTHERS \\
\hline CAN WRITE & 11 & 5 & 0 & 8 \\
\hline PRIMARY & 43 & 26 & 20 & 8 \\
\hline CLASS 8 & 8 & 16 & 11 & 10 \\
\hline MADHYAMICK & 7 & 8 & 4 & 1 \\
\hline HIGHER SECONDARY & 0 & 8 & 0 & 0 \\
\hline GRADUATE & 1 & 2 & 0 & 0 \\
\hline NOT HAVING CHILDREN & & 5 & 5 & \\
\hline NOT HAVING DAUGHTER & & & 30 & \\
\hline $\begin{array}{l}\text { NO INFORMATION } \\
\text { AVAILABLE }\end{array}$ & & & & 43 \\
\hline
\end{tabular}

Source: Field Survey

The family composition of the fishermen in this study is only concerned about the core family and not father, mother, brother or sister, etc. what can be observer from the table below is that few fishermen are having more than four children, 11 of them are having four children, 23 of them are having 3 children and 19 of them are having 2 children. 
IRA-Intemational Journal of Management E' Social Sciences

\begin{tabular}{|c|c|}
\hline FAMILY MEMBERS & NUMBER \\
\hline NOT HAVING CHILDREN & 5 \\
\hline 2 & 2 \\
\hline 3 & 5 \\
\hline 4 & 19 \\
\hline 5 & 23 \\
\hline 6 & 11 \\
\hline 7 & 4 \\
\hline 8 & 0 \\
\hline 9 & 1 \\
\hline TOTAL & 50 \\
\hline
\end{tabular}

Source: Field Survey

The chart below represents the same scenario that has been visualised in the above table.

\section{Family Size of the Surveyed Fishermen}

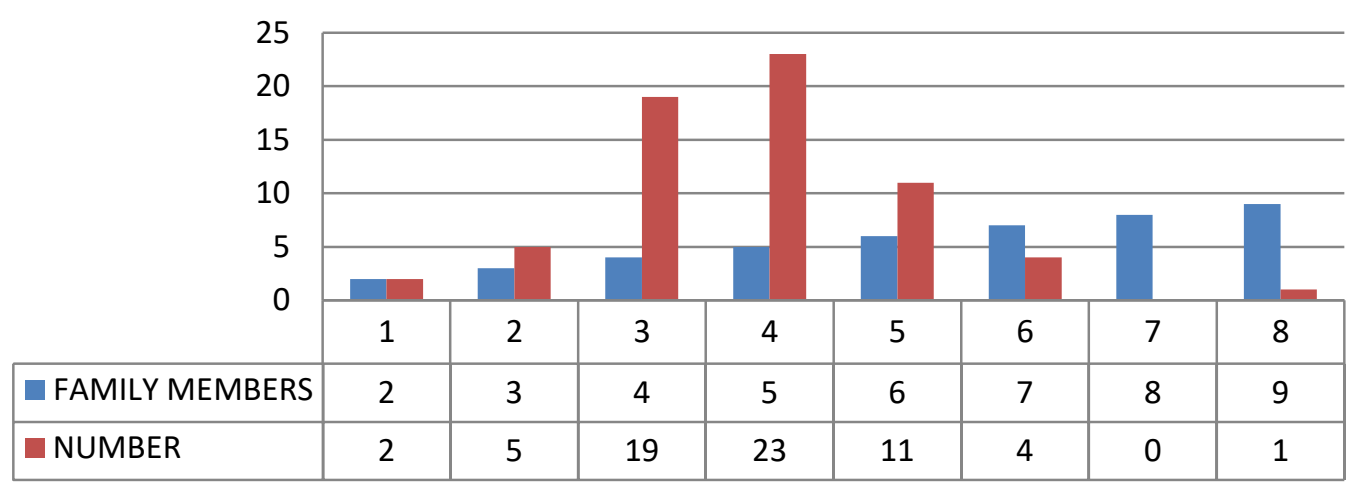

Source: Field Survey

\begin{tabular}{|l|r|}
\hline \multicolumn{2}{|c|}{ NUMBER OF CHILDREN } \\
\hline 0 & 4 \\
\hline 1 & 12 \\
\hline 2 & 24 \\
\hline 3 & 5 \\
\hline UN MARRIED & 1 \\
\hline TOTAL & 70 \\
\hline
\end{tabular}

Source: Field Survey

The above table reveals the number of children that these fishermen have. Out of these 70 respondents four of them are not having children at current point of time and only one of them is unmarried. Rural culture also believes in marriage in early twenties in case of male and 17-18 in case of female. 65 respondents are currently having 152 children. 


\section{Status of Children of Surveyed Fishermen}

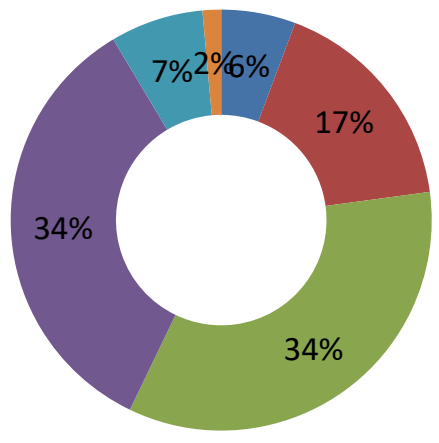

NONE

- ONLY CHILD

- TWO

THREE

FOUR

UN MARRIED

Source: Field Survey

Source: Field Survey

\begin{tabular}{|l|r|}
\hline STATUS OF CHILDREN & NUMBER \\
\hline CHILD & 7 \\
\hline SCHOOL GOING & 37 \\
\hline UNEMPLOYED & 9 \\
\hline WORKING & 12 \\
\hline UNKNOWN & 5 \\
\hline TOTAL & 70 \\
\hline
\end{tabular}

Children of the fishermen are mostly school going few are working and some are unemployed. 37 of the fishermen send their children to school. The table above is the representation of number of fishermen who responded in different occasion about their children current status. In case of fishermen having more than 1 child, the representation has been made on the basis of oldest children in the family and young ones are still school going.

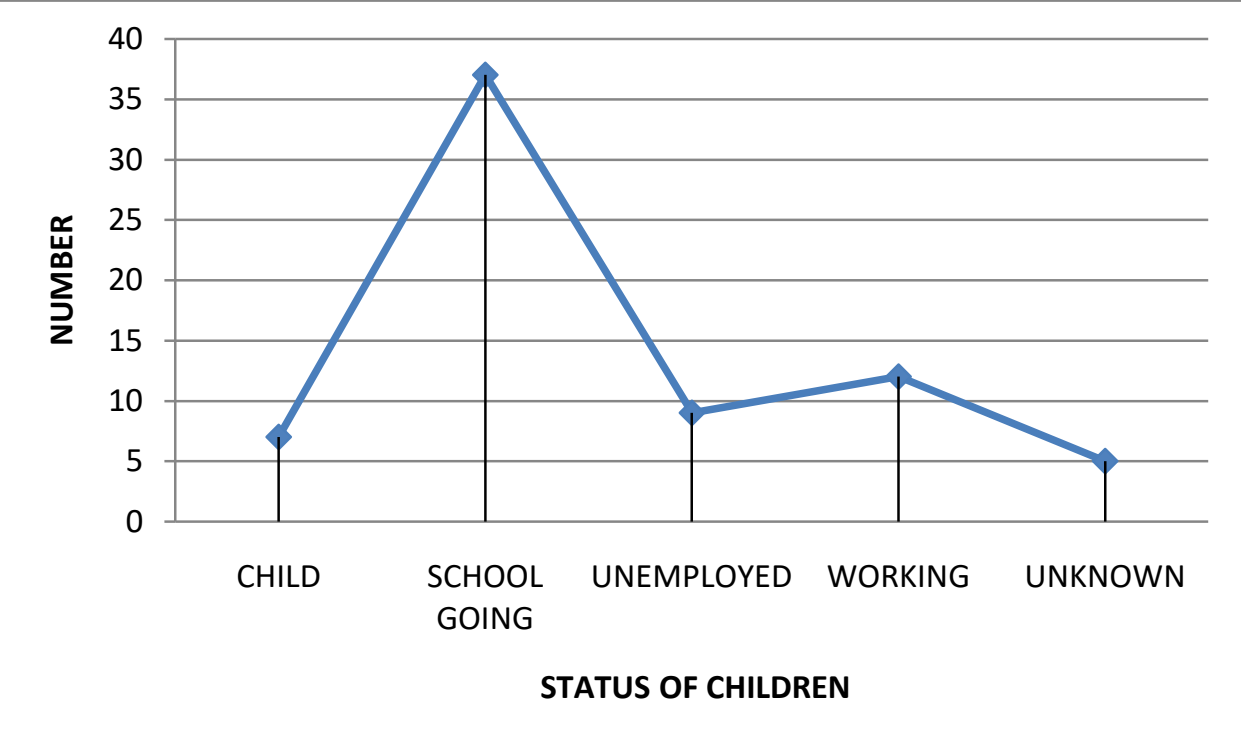


Source: Field Survey

A strange indistinguishable response is noticed from the answers of the fishermen in respect of same cases. All of the fishermen surveyed are Hindu in religion and works as a day labour in exchange of monthly wages. So the answers to the questions were quiet similar to each other. Almost 95\% of the fishermen are working 10-20 days in a month that means in these 10-20 days the fishermen are boating through the seas to get a good catch involving 6-7 hours of fishing in a day. The most astonishing part of fisherman's struggle is that they do not end their day with only one work of fishing, most of them are involved in other activities to generate extra income for a better and prosperous future.They employ the process of fishing till mid of April and again restart it after 14th June. The period between 15th April to 14th June is considered to be the breeding periods of marine fishes and the time grow. The concept is also encouraged by the fishing industry and supports it to the full extent and no fisherman goes for fishing in this time period. But this period doesn't turn out to be holidays for these fishermen as they have no future savings a constant flow of income is required to sustain their family and earn livelihood. Most of them being the head of the family are responsible for running the family and decisions regarding the governance of the family lie in their hand. If fishing is not the current income they shift to other activities to maintain the flow of income in between 15th April and 14th June. The chart below is a graphical representation of the number of fisherman having boat or not. Sixty one out of seventy do not have a boat as it requires huge capital investments but the remaining nine fishermen of this study enjoy the pride of owning a boat. A fisherman considers him free when he owns a boat so that an initiative towards a trade can be started or else he remains a day labour in big boats.

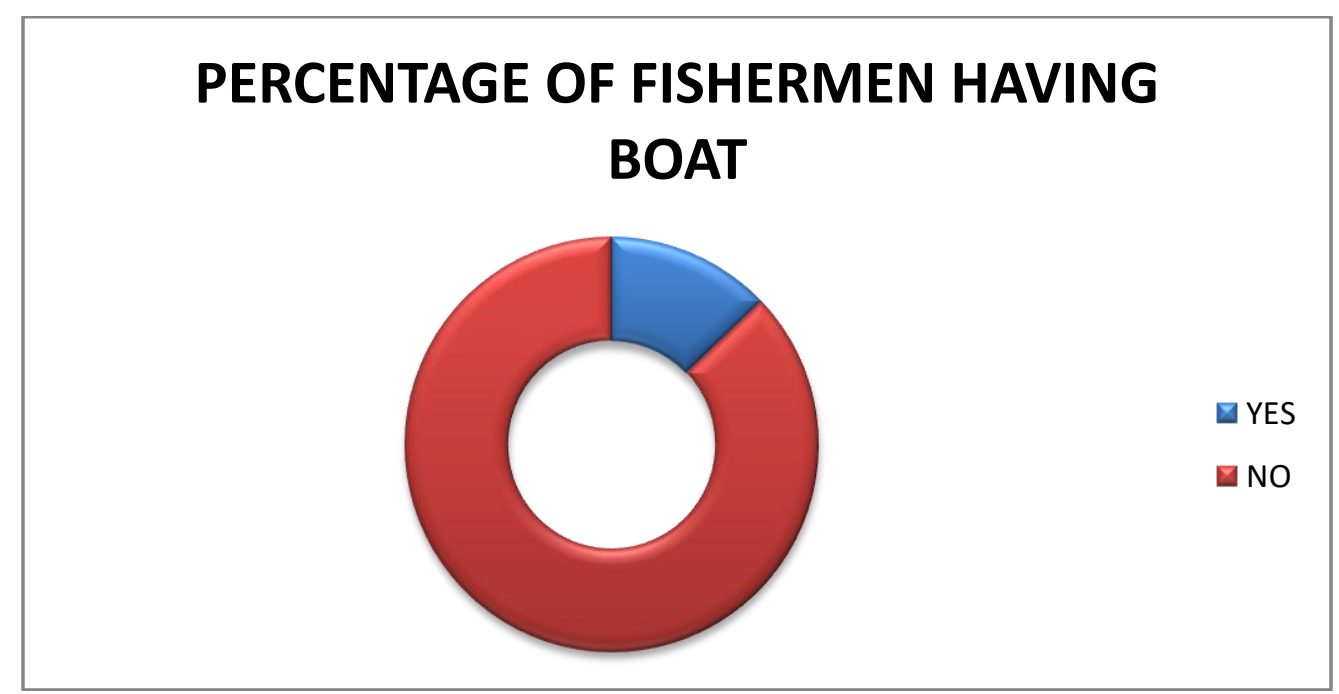

Source: Field Survey

Nine of the fishermen are having boat which leads the study to some further query of do they ride the boat or lent it to other fishermen or do they go for fishing in other boats. The entire fisherman having boat do not go for fishing in other boats and rides their own boat. Of these nine fishermen four of them lent their boat on rent as well as go for fishing also which accumulates their income from two different sources. While the remaining five fishermen go for fishing on their boat and takes portion of fish catch as their source of income and sells that portion to convert them to cash. The pie chart below is the graphical representation of the fisherman having boat and their source of income. 


\section{SOURCE OF INCOME FROM BOATING}

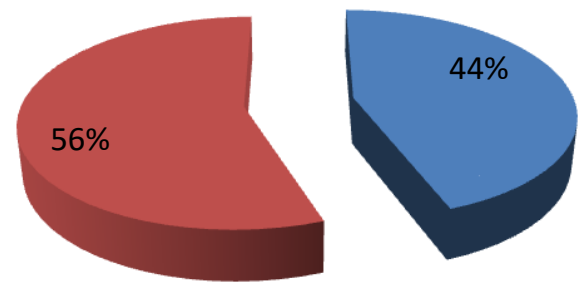

- PORTION OF FISH CATCH

- PORTION OR LET OUT

Source: Field Survey

\begin{tabular}{|c|c|}
\hline TYPE OF BOAT & NUMBER OF FISHERMEN \\
\hline BIG & 3 \\
\hline MEDIUM & 66 \\
\hline SMALL & 1 \\
\hline
\end{tabular}

Source: Field Survey

The above table shows the size of boat involved in fishing purposes, small boats are very compact and ranges a very little area of fishing from 1-2 kilometres maximum. Medium sized boat can range to 2-5 km and large boats can range from $50-70 \mathrm{~km}$. as the size varies, price and capacity also varies simultaneously a fisherman can only afford to purchase and maintain small or medium boat. Fisherman in modern days are referred as day labours as the big boats and trawlers works automatically and minimum manual effort is required, primary and only work is to differentiate the fishes that are being caught so that it can be auctioned immediately after landing. There is no requirement to categorise these men as anyone who approaches can work as fish labours in these motorised boats with a monthly remuneration of 6000-8000 rupees. But the driver of the boat is paid on a percentage on catch basis as he is the one responsible for catching fishes and sailing in the required area. Till today there is no use of technology for catching fish so the investors are totally dependent on the driver of the boat and the boats are equipped with wireless sets, compass and GPS to avoid getting lost in the middle of the sea. It is the experience of the driver that drives towards profit in fishing business.

Fishing as well as fishing net can be divided to three categories:

1. Small - In this segment small manual boats are used to catch fish and the net size is also small. Which ranges up to 2 kilometres and over-all cost of boat and fishing net may range up to 3 lakh Rupees.

2. Medium - Motorised boats or launch which goes around 2-5 kilometre deep for fishing and uses monophilament net which is dipped in the water for an hour and then recovered and returns for selling. These boats return within a day and cost around 50 lakhs.

3. Large - These trawlers has a wide range of 50-70 kilometre fully automatic fish catching with 8-10 men for processing and grading the fish. Trolling nets are like giant pockets with a low density at the front for big fishes and density increases in the end to catch small fish. Trawlers may cost up-to 1 crore rupees. Fishing in this category can go up-to 20 days so backup of enough food and ice for preservation is preloaded.

Fishermen not having boat go to fishing either on partnership basis or waged basis with the fishermen having boat. Usually these fishermen do not lent a boat as they are afraid of the risks involved in trading of fishes and are stagnant with basic wages that they receive from fishing. There is no requirement for a chart or table as none of these boats in which the fishermen goes for fishing have modern techniques to enhance their efficiency of fish catch. Nine of these fishermen have fishing net which are utilised for fishing purposes and do not require to borrow from others. Whereas, 61 fishermen opt for partnership with the net owner and boat owner by creating a cartel of 10-12 members fishing together on an agreed share basis. 
IRA-International Journal of Management Eి Social Sciences

\begin{tabular}{|c|c|c|c|}
\hline MONTHLY INCOME & BOAT & FISHNET & NUMBER OF FISHERMEN \\
\hline 3000 & NO & NO & 18 \\
\hline 4000 & NO & NO & 12 \\
\hline 5000 & NO & NO & 3 \\
\hline 6000 & YES & YES & 2 \\
\hline 8000 & YES & YES & 4 \\
\hline 12000 & YES & YES & 1 \\
\hline
\end{tabular}

Source: Field Survey

Responses of the fishermen were noticed to be same in respect of their monthly and quarterly income so there is no requirement of ranging the data or grouping of data is felt. Specific answers regarding weekly income, which is exactly the monthly income each quarter, were received from the respondents which did not vary from monthly income and no dispersion was noticed. Fishermen having a monthly income of 6000 and more have either fishing net or boat, while others with income of less than 6000 are only waged workers.

\begin{tabular}{|c|c|}
\hline WEEKLY INCOME & NUMBER OF FISHERMEN \\
\hline 800 & 17 \\
\hline 1000 & 42 \\
\hline 1200 & 2 \\
\hline 1500 & 3 \\
\hline 2000 & 2 \\
\hline 4000 & 4 \\
\hline
\end{tabular}

Source: Field Survey

\begin{tabular}{|c|c|c|c|c|}
\hline $\begin{array}{c}\text { MONTHLY } \\
\text { INCOME }\end{array}$ & $\begin{array}{c}\text { EARNINGS } \\
\text { FROM LENDING } \\
\text { THE BOAT }\end{array}$ & $\begin{array}{c}\text { EARNINGS } \\
\text { FROM LENDING } \\
\text { NET }\end{array}$ & REPAIRING COST & $\begin{array}{c}\text { REPAIRS OF } \\
\text { NET }\end{array}$ \\
\hline 6000 & - & - & 500 & 1000 \\
\hline 8000 & 300 & 200 & 500 & 1000 \\
\hline 6000 & - & - & 500 & 1500 \\
\hline 8000 & - & - & 500 & 2000 \\
\hline 6000 & 200 & - & 500 & 1500 \\
\hline 12000 & 2000 & 1000 & 500 & 1500 \\
\hline 12000 & 1000 & 1000 & 2000 & 1500 \\
\hline 12000 & 200 & 200 & 1000 & 1500 \\
\hline 12000 & 200 & 200 & 1000 & 1500 \\
\hline
\end{tabular}

Source: Field Survey

Fishermen who have income above 6000 own fishing net or fishing boat and only they can answer the question relating to earning from lending the boat, earnings from lending net, repairing cost of the boat and repairs of the net. An incomplete set of information is received from few fisher men but the true and actual representation has been made to uplift the actual scenario. When it comes to income of the respondents most of them would prefer silence or reduce their earnings and try not to disclose the actual figures. The parity in answers can be noticed in the previous monthly and weekly income comparison and the boat owners report that six out of nine incur about 500 rupees per month in connection to their repairs of boat. While other 3 showcases higher repairing cost per month, ranging from 1000-2000. Repairing cost of net is usually higher than repairing cost of boat as it is perishable in nature and not as durable as e boat. So the reported cost of repairing a net ranges from 1000-2000 rupees. Income from lending the boat or net is comparatively low than repairing cost as these boats are not lent daily rather a few times in a month. So the accumulated income from own fishing and boating is the income that they generate in a month. 
NREGA initiative has helped their family to boost up the income level that they used to receive earlier. $90 \%$ of the fishermen are involved in NREGA works and only 5 of them have riskshaw or toto as their alternative source of income and few are involved in the processing of dry fish totalling it to $100 \%$.

\section{EXPENDITURE PATTERN OF SURVEYED FISHERMEN}

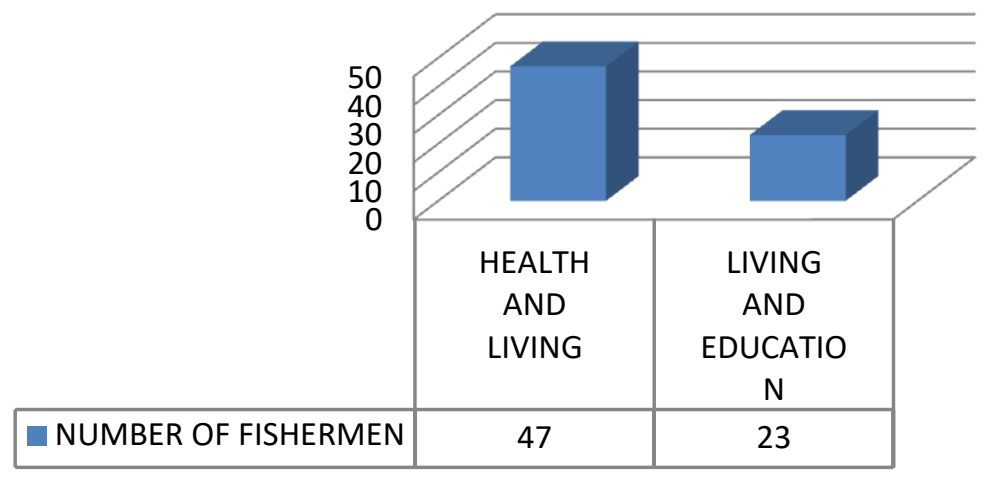

Source: Field Survey

\section{SECTORWISE EXPENDITURE OF THE SURVEYED FISHERMEN}

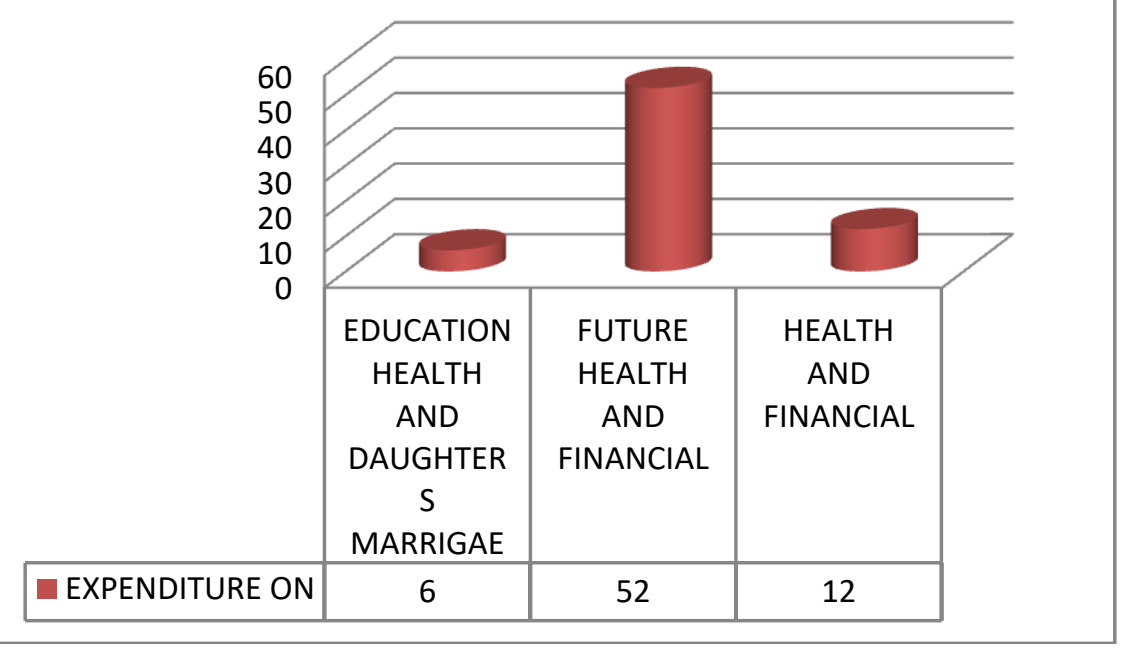

Source: Field Survey

Sixty nine of the respondents save a part of their income for future dynamics except one fisherman. Savings nowadays have been encouraged as banks have spread their helping hands in rural economy also. The availability of services is the only reason they are being availed and all the fishermen save their money in banks. The main purpose of saving is for education, health, daughter's marriage and future financial requirements. The responses were gathered from all the seventy fishermen and the areas focused by the fishermen are the factors that concern them the most is represented in the above table. 52 of the respondents believe that they save for health, future uncertainties and financial requirements in the dynamic future. Other 12 believes that health and future financial requirements are most important concern of their future while the remaining six of them agree on the matter of daughter's marriage also. 
IRA-International Journal of Management E̊ Social Sciences

\begin{tabular}{|c|c|}
\hline BORROWINGS & NUMBER OF RESPONDENTS \\
\hline SELF HELP GROUP & 53 \\
\hline NO BORROWINGS & 17 \\
\hline
\end{tabular}

Most of the respondents need the support of finances for differentiated purposes varying according to their needs. So the role of financial services are recognised and there comes the role of microfinance which has conquered the rural sectors of India by meeting the requirements of the people with small credit needs at lower rates of interest. Self Help Group (SHG) a poverty reduction tool to curb poverty was introduced during 90's by Government, Banks, Financial institution and NGO. The movement started late in Bengal but accelerated quickly due to collaborative efforts. A peer controlled, voluntary informal group that collectively perform activities to fulfil mutual purposes. With a maximum women contribution, a group consist of 15-20 members who come together for social and financial support to each other. It is relevant for people Below Poverty Line (BPL) to emerge to new standards of life, increasing income and self-reliant. The fishermen are concerned with their own income and are less concerned about the income made by women. SHG has an all women culture which is not uplifted by men so they are less bothered about the incomes generated by women. When the fishermen were asked about the change in income after joining SHG, all of them answered that they didn't notice any change in family income after joining SHG.

\begin{tabular}{|c|c|c|}
\hline Asset Evaluation of the Fishermen & \\
\hline ASSETS & YES & NO \\
\hline ELECTRIC METER & 67 & 3 \\
\hline SEWING MACHINE & 4 & 66 \\
\hline WATER PUMP & & 70 \\
\hline MOBILE PHONE & 59 & 11 \\
\hline TV & 29 & 41 \\
\hline BIKE & 1 & 69 \\
\hline ENGINE VAN & 9 & 61 \\
\hline RADIO & 2 & 69 \\
\hline TRACTOR & 1 & 69 \\
\hline MOTOR CAR & & 70 \\
\hline
\end{tabular}

All the seventy respondents were questioned about their current asset holdings to get an idea of their standard of living. The obvious results came out through the survey where the answers show that almost every fisherman is living the same standard of living when compared to other fishermen. Sixty seven fishermen are having electric meter and the only reason is that the government provides it or else it would not be noticed. The above table answers a lot about the lives of fishermen. None of them are having a motorcar or water pump which represents that neither of them are rich and are not having the requirement to store water as they do not have a two stored building. Radio technology has faded away by the dominance of television so only two of the 70 respondents have radio whereas 29 of them are having television. Influence of technology can also be noticed in these rural areas of Gadadharpur and Duttapur in which fifty nine respondents are having mobile phones for connectivity purposes which help them to communicate with other fishermen. The ratio of mobile usage is high in fishermen but they use basic mobile phones not smart phones. So, their accessibility to internet is restricted resulting in limitation of knowledge. Nine of the fishermen have engine van by which they earn extra money for living. Rural areas have the rural technology of engine van which is made by the engine of old and small boats but structured in a van which reduces the human effort and increases the carrying capacity as it is a machine just like a car or truck but causes more pollution in respect to other vehicles. 
IRA-International Journal of Management Eి Social Sciences

\begin{tabular}{|l|c|c|}
\hline \multicolumn{2}{|c|}{ DO YOU AGREE } \\
\hline & YES & NO \\
\hline DOWRY SYSTEM & - & 70 \\
\hline CHILD MARRIAGE & - & 70 \\
\hline POLYGAMMY & - & 60 \\
\hline INTERCAST MARRIAGE & - & 70 \\
\hline INTER RELIGION MARRIGAE & 70 & - \\
\hline WOMEN JOB RESERVATION & - & 70 \\
\hline CHILD LABOUR & 70 & - \\
\hline CHILD IMMUNATION & & 69 \\
\hline
\end{tabular}

The above chart was based on questioners on the social awareness of the respondents to evaluate the mentality of the fishermen about these specific social issues. The results may be biased to a particular answer but the answer to the issues in our society is fair. All the fishermen are against dowry system, child marriage, polygamy, inter-caste marriage, inter religion marriage, and child labour. Women job reservation and child immunation is supported by them which enclose the understanding, awareness and importance of women and children in their lives.

\begin{tabular}{|l|c|c|}
\hline \multicolumn{2}{|c|}{ HEALTH CHECKUP } \\
\hline & YES & NO \\
\hline PRIVATE DOCTOR & 1 & 69 \\
\hline LOCAL MEDICINE & 1 & 69 \\
\hline HERBAL MEDICINE & 69 & 1 \\
\hline BABA(LOCAL) & - & 70 \\
\hline GOVERNMENT & 70 & - \\
\hline NURSING HOME & - & 70 \\
\hline DO NOTHING & - & 70 \\
\hline
\end{tabular}

Sickness cannot be avoided no matter how much precaution we take. There is no specific disease related to fishing in marine water but general diseases can occur time to time and not to mention, life taking diseases can come anytime. But the rural fishermen of these areas of Digha, West Bengal seems to depend on local and herbal medicine if government treatment is not available. Lack of monetary backup and high charges made by the private doctor, the fishermen usually avoid costly check-ups or treatments. The truth is these men are hardworking enough which increases their immunity which is also reflected in the age chart and table. Most of the workforce is in the age group of 28-48 and even fishermen are found in the age group of 58-68. Sickness can't even dominate them for a long time they recover eventually but the only sickness they can't get out of is financial sickness.

\section{Conclusion}

Marine fishing industry has evolved as an important sector of agriculture which makes a significant contribution to the GDP. At the initial stage this industry noticed disparity due to many factors that imbalanced the growth. But with accelerating time a steady growth was noticed in the overall production and procurement of fishes. Technology has played a significant role in development of this industry and the results are visible. Gujarat, Kerala, Maharashtra, Tamil Nadu, Andhra Pradesh have manifested remarkable growth throughout the years whereas states like Pondicherry, West Bengal, Odisha, Lakshadweep, Daman and Diu, Andaman and Nicobar Islands have shown consistent trend of slight improvement irrespective of the opportunities that they have of a vast costal coverage. West Bengal has not displayed any consequential development in fishing industry and the socio economic conditions of the fishermen are still underdeveloped. Free resources are being procured by the businessman and being sold at high rates which also involves the cost of exploiting the weak and deprived fishermen. Basic governmental facilities are provided to them by considering them as rational weak citizens of the country but no special recognition is provided. Technological developments, skilled labour, heavy 
investments and many other factors have backed the fishing industry and will take it to new heights in coming future but the fishermen are just considered to be a day labour nowadays. Improvement of socio economic condition of these labours will only be possible by the government by adopting a set of infrastructural and developmental steps.

\section{References:}

[1]. Chidambaram, K., and Soundrarajan, A. (1997).Marine Fish Supplies in Tiruchendur- A Case Study, Fishing Chimes, 2(9): 1997, pp.58-61.

[2]. CMFRI(1977).Indian Fisheries 1947-1977, Issued on the Occasion of the Fifth Session of the Indian Ocean Fishery Commission, Cochin, 1977, pp.74-77.

[3]. CMFRI(1985). Newsletter, Focus on Artisanal Fisherfolk, Vol.27-28: 1985, pp.8-12.

[4]. Durairaj, N (1981). A Study of Marine Fishing Industry in Thanjavur District, Unpublished Ph.D. Thesis, Madurai Kamaraj University, 1981, p.230.

[5]. Fernando, Ambrose (1981).Community Development and Infrastructure Facilities for Improving the SocioEconomic Conditions of Fishermen, CMFRI Bulletin, 30: 1981, pp.45-55.

[6]. James, P.S.R (1990).Marine Fisheries not Fully Tapped, The Hindu Survey of Indian Agriculture, 13 (7): 1990, pp.203-205.

[7]. Nair, M.K.R. Girija, S. (1998).Application of Low Cost Technologies in Fish Processing and Its Prospects as a Vocation for Fisherwomen of Kerala, In Hameed, M.S., Kurup, B.M., (Eds.) Technological Advancement in Fisheries, Publ. No.1, School of Industrial Fishing, Cochin, 1998, pp.478-484.

[8]. Sehara, D.B.S., Panikkar, K.K.P., and Karbhari, J.B. (1992). Socio- Economic Aspects of the Monsoon Fisheries of the West Coast of India, CMFRI Bulletin, 45: 1992, pp.242-250. 